UDC 930 Druget

Ђура Харди

Оригинални научни рад

Универзитет у Новом Саду

примљено: 1. јул 2011

Филозофски факултет

прихваћено: 1. октобар 2011

Одсек за историју

hardyg@ptt.rs

\title{
ИСТОРИОГРАФИЈА О ПОРОДИЦИ ДРУГЕТ У СРЕДЊЕМ ВЕКУ*
}

Сажетак: У раду се истражује анжујска племићка породица Другет у средњем веку као историографска тема. Другети су протеклих 200 година непосредно или посредно предмет истраживања осам европских историографија. Постигли су то захваљујући пре свега свом интересантном француском и напуљском пореклу и утицају који су као палатини остварили у Угарској у првој половини XIV века. Ипак, кључна тачка за историографију у погледу изучавања историје ове породице било је спаљивање Напуљског државног архива 1943. године. Од тада историчари су се усредсредили на присуство породице у средњој Европи. Тек новија сазнања о радовима италијанске историографије поново су актуелизовала тему о пореклу Другета; „проблему” који заправо стоји у зачетку критичке историографије посвећене овој породици.

Кључне речи: Другети, историографија, историја средњовековних племићких породица.

Историја средњовековних породица је посебна област историографије која од историчара захтева у најмању руку два смела истраживачка „путовања.” У идеалним околностима, њихови правци, поплочани изворима, требало би да се пажљиво испреплићу и на крају споје пред заокруженим циљем званим монографско дело. Први правац је унутрашњи и односи се на генеалошки, биографски и просопографски приказ постојања једне породице. Други има за циљ да се породица, односно њени чланови, смести у реално историјско време и простор да би се у конкретним друштвеним, политичким и материјалним оквирима могло што верније сагледати њихова улога и место у одређеној епохи. У крајњој линији пред писца такве повести је постављен задатак да се породична нит водиља - кроз приказ успона, падова или стагнације без кидања и непотребног петљања „провуче” 
кроз један дужи историјски ток. За средњовековну епоху једна од битних одредница породичног успеха племићког друштва је „посед.” Захваљујући расположивим изворима, врло често је управо поседу додељена улога тега на историографској ваги којим ваља измерити богатство, друштвени положај и моћ једног рода. Стога је историја средњовековне породице и историја њеног possessionis-a. У трагању за „употребним” историографским садржајем извори су и у случају средњовековне фамилије Другет усмерили писце на карактеристично поље истраживања које се у суштини није разликовало од сродне научне литературе. То међутим није значило да посреди није био (и остао) прави историографски изазов.

Породица Другет јесте историографски изазов. О томе сведочи чињеница да ова тема већ преко два столећа привлачи пажњу историчара. Наиме, Другети су били племићка породица, по свему судећи француског (или провансалског) порекла. У пратњи Анжујаца учествују у освајању јужне Италије од Хоенштауфоваца. Од помена из 1267. године сусрећемо их као одане службенике на двору чланова анжујске владарске династије у Напуљу и Салерну. Године 1300. један од њих, Филип, у пратњи претендента и будућег угарског краља Карла Роберта креће у Угарску да би у новој домовини 1323. године постао највиши државни великодостојник - краљевски палатин. Као његови наследници у Угарску из Напуљске краљевине стижу и његов братић Виљем и брат Жан с породицама. Између 1323. и 1342. године палатинско достојанство у Угарској припада Другетима. Иако странци, они постају најмоћнија, најбогатија и најутицајнија угарска великашка породица тог доба. Господари су великог дела североисточне Угарске. Смрћу палатина Виљема и његовог господара краља (1342), породица доживљава пад. Каснији избор Виљемовог брата Николе за јудекса краљевске курије (1354-1355) у том погледу није могао ништа да промени. Од друге половине XIV века породица је лишена политичког утицаја на краљевском двору, али је сачувала баронски статус захваљујући још увек великим поседима у жупанијама Земплин и Уж (данас источна Словачка, Закарпатска Украјина). Докраја средњег века њихови поседи остали су упориште породичне моћи, а Другети су се стицајем нових околности морали уклопит у структуре локалног племићког друштва.

У панонском миљеу током последњих деценија XVIII и почетком XIX века несвакидашње порекло и локални значај (тада већ изумрле) магнатске породице Другет привукли су пажњу великих историка Спишке, Шаришке и Земплинске жупаније Карла Вагнера (Carolus Wagner) и Антона Сирмаија (Antonius Szirmay). Био је то почетак критичке историографије о овом роду. ${ }^{1}$ Поменута господа су своја сазнања о „салернитанском пореклу” Другета - питању за које смо уверени да је било пресудно за развој историографије о породици - црпела из старијег дела чувеног књижевника и учењака Ј. Бокацијус (Joannes Bocatius) односно Јохана Бока

\footnotetext{
* Рад је настао као фазни резултат републичког пројекта број 177002 под називом Војвођански простор $y$ контексту европске историје.

${ }^{1}$ Carolus Wagner, Collectanea genealogico-historica illustrium Hungariae familiarum que jam interciderunt, Decas III, Posonii, Pestini et Lipsiae 1802, 33-55; Notitia topographica, politica inclyti comitatus Zempléniensis per Antonium Szirmay, Budae 1803, 76; Notitia historica comitatus Zempléniensis per Antonium Szirmay, Budae 1804, 99-104.
} 
(Johann Bock), како је гласило његово право име. „Замољен” од једног директног палатинског потомка, Бокацијус се крајем XVI века прихватио, наравно, као и сви честити људи од заната - за извесну суму златника, да проучи историјат ове тада угледне и богате угарске магнатске породице. Учењак је свој рад с напоменом о пореклу Другета преточио у панегирик у стиховима и публиковао га у делу Hungaridos libri poematum $V$, изашлом у Бардејову 1599. године. ${ }^{2}$ Између Бокацијуса и Вагнера, на путу од дела која су истовремено извор и претеча критичке историографије, морамо поменути књигу Иштвана Барањаја (Barinyay István), Palatini regni Hungariae публиковану у Трнави 1753, у којој је, уз неке занимљиве податке, први пут описано палатинство три члана породице Другет. ${ }^{3}$

Ерудита, историчар и генеаолог Карло Вагнер (1732-1790) био је заправо први истраживач који је систематично приказао прошлост и родослов тада већ изумрле породице Другет. По нашем увиду, Вагнеров текст о Другетима је публикован постхумно, 1802. године, у трећој свесци знаменитог дела Collectanea genealogico-historica illustrium Hungariae familiarum que jam interciderunt. Посветивши скоро цео свој стваралачки живот сакупљању и публиковању дипломатичких извора из области североисточне Угарске (данас источне Словачке) где су средишта и поседе имали Другети, Вагнер је у својим спишким и шаришким дипломатарима не само објавио важна документа за ову породицу, већ их је затим искористио за писање рада о Другетима. ${ }^{4}$ Потоњи историчари и зналци извора, попут Иштвана Катоне (Stephanus Katona) ${ }^{5}$ или Антона Сирмаија ослањали су се на вредно дело Карла Вагнера. ${ }^{6}$ Нови преглед генеаологије породице дао је Иван Нађ (Nagy Iván) 1858. године у трећем тому познатог дела Magyarország családai. ${ }^{7}$

Спознаја о загонетном „салернитанском пореклу” Другета записаном давно код Бокацијуса историчарима није давала мира. Салерно као колевку породице напомиње и чувени Ђерђ Фејер (Fejér Georgius) у једанаестом тому Codice

\footnotetext{
${ }^{2}$ M. Joannis Bocatii Poëtae Laureati Caesarei Hungaridos libri poematum V, Funeri Spectabilis, Magnifici et generosissimi Domini, D. Stephani Drugeth, Lib. Bar. de Homonna etc, Bartphae 1599, 430, (428-438); Ioannes Bocatius, Opera quae exstant omnia, Poetica 1, ed. Franciscus Csonka, Budapest 1990, 580 etc.; О Бокацијусу упор.: Magyar írók, élete és munkái, írta József Szinnyei, I, Budapest 1891, 1114-1118.

${ }_{3}^{3}$ Palatini regni Hungariae bello paceque clarissimi, (Barinyay István), Tyrnaviae 1753, 64-68; Иштван Барињаји је заправо у писању наведеног дела користио и допунио радове старијих аутора Гашпара Јонгелинуса (Jongelinus Gáspár) и Мартона Сентивањија (Szentiványi Márton). Упор.: Szinnyei, Magyar írók, I, 586-587.

${ }^{4}$ Carolus Wagner, Analecta Scepusii sacri et profani, tomus I-IV, Viennae (I-II); Posonii et Casoviae (III-IV) 1774-1778; Carolus Wagner, Diplomatarium Comitatus Sarosiensis. Posonii et Cassoviae 1780; О Карлу Вагнеру: Milota Malovecká, Karol Wagner /1732/1790/ historik Spiša a Šariša, Prešov 2009.

${ }^{5}$ Historia critica regum Hungariae stirpis mixtae, a Stephano Katona, tomulus I, ordine VIII, (ab anno Ch. 1301 ad annum usque 1331), Budae 1788, 621, etc.

${ }^{6} \mathrm{O}$ значају Вагнеровог рада лепо сведочи следећа чињеница. У Прешовском државном архиву у збирци породичног архива Другет налази се звучни документ Geneaologia Druget ab Anno 1322. На маргини документа је аутор родословља написао да га је саставио на основу Вагнера. ŠA Prešov, Druget H. inv. с̌. 923 sign A-9.

${ }^{7}$ Iván Nagy, Magyarország családai, Czímerekkel és nemezedékrendi táblákkal, III, Pest 1858, 398-405.
} 
Diplomatico Hungariae. 8 Након вредних истраживања и прикупљања напуљских извора важних за мађарску историју од стране Липота Оварија (Óváry Lipót) међу којима су се нашли и они о Другетима, у пролеће 1875. године Јожеф Хампел (Hampel József) je специјално због истраживања порекла Другета предузео пут у Напуљ да би походио тамошње архиве и библиотеке. До данашњих дана скоро непревазиђене резултате свог рада Хампел је публиковао на страницама часописа Századok 1881. године. ${ }^{9}$ Поред исписа нових података о помену Другета у служби анжујске династије у Краљевини Сицилији, Хампел је дошао до закључка да корене породице не би требало тражити ни у Салерну ни у Напуљу, већ негде у Француској, одакле су Другети као присталице Карла I Анжујског стигли у Италију. Хампел се посебно позабавио хералдиком, повезавши познати угарски грб Другета на коме су стајали дроздови са врло сличним грбовима у Напуљу, посебно оним који је припадао такође анжујској, француској породици Мерло пореклом из Пикардије, те је поставио питање њиховог сродства. Хампеловој расправи о пореклу породице придружио се 1891. године чувени генеалог и историчар Мор Вертнер (Wertner Mór) који је, ослонивши се на француску генеалошку и хералдичку литературу о племенитим Мерлоима, био увререн да порекло Другета ипак треба тражити у Италији. $^{10}$

Бавећи се нововековном историјом породице, постојећа сазнања о првим Другетима 1899. године је приказао у свом делу и Ласло Peз (Réz László). ${ }^{11}$ Али, заправо, тек тридесетих година XX века чланком O преuзима Другета (A Drugetek öseiröl) плодну расправу на ту тему је наизглед заокружио Иштван Мишколци (Miskolczy István). ${ }^{12}$ Овај историчар угарско-напуљских односа у доба Анжујаца спровео је озбиљна истраживања у Archivio di Stao di Napoli на основу којих je допунио резултате радова својих претходника. Такође, у својим делима о анжујским везама и утицајима између Угарске и Напуљске краљевине Мишколци није изоставио да помене утицај Другета. ${ }^{13}$ Показало се да је то било од непроцењивог значаја, јер након тога, у Другом светском рату, Напуљски архив је 1943. године био спаљен. ${ }^{14}$ Изгледало је, наиме, да се поред већ познатих сазнања и недоумица откривених на југу Италије историографија надаље може посветити само деловању Другета у средњој Европи.

Другети су своје место „очекивано пронашли” у готово свим општим делима посвећеним владавини и добу Анжујаца у Угарској. ${ }^{15}$ У радовима великих

\footnotetext{
${ }^{8}$ Codex diplomaticus Hungariae ecclesiasticus ac civilis, ed. Georgius Fejér, Budapest 1829-1844, XI, supplementa, 444.

${ }^{9}$ József Hampel, A Drugetek öseiröl, I-II közlemény, Századok (Sz) 1881, 133-145, 207-213.

${ }^{10}$ Mór Wertner, A Drugeth-ek genealogiájához, Turul (T), 9, 1891, 151-154.

${ }^{11}$ László Réz, Drugetek és Homonna reformátiója, Sátoralja-újhely, 1899.

${ }^{12}$ István Miskolczy, A Drugetek öseiröl, T. 50, 1936, 1-5.

${ }^{13}$ István Miskolczy, Anjou-királyaink reformjai és a nápolyi viszonyok, I-II, Sz 1932, 306-322, 393-407; Исти, Magyar-olasz összeköttetések an Anjouk korában, Budapest 1937.

${ }^{14}$ Archivo di stato di Napoli, Guida generale degli Archivi di stato italiani, vol. III, N-R, Roma 1986, 20.

${ }^{15}$ Последње књиге у низу: Pál Engel, Gyula Kristó, András Kubinyi, Magyarország története 1301-1526, Budapest 2002; Enikő Csukovits, Az Anjouk birodalma 1301-1387, Magyarország története, 5, Budapest 2009.
} 
историчара Антала Пора (Pór Antal) ${ }^{16}$ и Балинта Хомана (Hóman Bálint), ${ }^{17}$ посебно у монографијама Ђуле Кришта (Kristó Gyula) посвећеним Матеју Чаку, бици код Розгоња, феудалној раздробљености Угарске у освит анжујског доба, или у његовој књизи о анжујским походима. ${ }^{18}$ У низу аутора мора се издвојити име великог медиевисте Пала Енгела (Engel Pál). Стварајући своја дела на претежно необјављеној дипломатичкој грађи, Енгел је без сумње био најбољи зналац средњовековне историје породице Другет. То се делимично може видети у његовој одредници Druget публикованој у Korai magyar történeti lexikon-у ${ }^{19}$ или у монографији о племићком друштву средњовековне жупаније Уж (Ung), где су Другети повремено били жупани и највећи поседници. ${ }^{20}$ У чланку Nagy Lajos ismeretlen adományreformja ${ }^{21}$ овај историчар је појаснио околности разбаштињења породице 1342. године. Ипак, два Енгелова рада представљају без сумње незаобилазни водич у сакупљању кључних извора за проучавање историје Другета у првој половини XIV века. Реч је о чланку у коме Енгел истражује борбу Карла Роберта против угарских великаша, током које се уздигао и будући палатин Филип Другет (Az ország újraegyesítése, I. Károly küzdelmei az oligarchák ellen (1310-1323)) ${ }^{22}$ и капиталном делу мађарске медиевистике Magyarország világi archontológiája, коме је касније, у новој форми, додата средњовековна генеалогија. ${ }^{23}$ По нашем уверењу, поред Енгела, још један историчар је имао изузетан утицај на стварање историографске представе о улози Другета у Угарској у првој половини XIV века. Мислимо на Агнеш Курц (Kurcz Ágnes) и њену књигу Lovagi kultúra Magyarországon a 13-14. században у којој ауторка зналачки говори о Другетима као најзначајнијим носиоцима витешке културе нове анжујске аристократије у Угарској. ${ }^{24}$

Студије Вилмоша Фракноија (Frankl, Fraknói Vilmos), Лајоша Њерша (Nyers Lajos), Гезе Иштвањија (Istványi Géza) или Ивана Бертењија (Bertényi Iván) o функционисању (судске) власти и канцеларије угарских палатина и јудекса краљевске курије уједно су и радови који се односе на Другета у улози носиоца наведених највиших државних служби. ${ }^{25}$ Стручњацима су пажњу привукли печати и

\footnotetext{
${ }^{16}$ Antal Pór, Gyula Schöner, Az Anjou ház és örökösei (1301-1439), A magyar nemzet története, szek. Szilágyi Sándor, Budapest 1895.

${ }^{17}$ Bálint Hóman, Gli Angoini di Napoli in Ungeria 1290-1403, Roma 1938; Bálint Hóman - Gyula Szekfü, Magyar történet, II, írta Bálint Hóman, Budapest 1939.

${ }^{18}$ Gyula Kristó, Csák Máté tartományúri hatalma, Budapest 1973; Исти, А rozgonyi csata, Вudapest 1978; Исти, A feudális széttagolódás Magyarországon, Budapest 1979; Исти, Az Anjou-kor háborúi, Budapest 1988.

${ }^{19}$ Pál Engel, Druget, Korai magyar történeti lexikon (9-14. század), főszerkesztő Gyula Kristó, Budapest 1994, 174.

${ }^{20}$ Pál Engel, A nemesi társadalom a középkori Ung megyében, Budapest 1998.

${ }^{21}$ Pál Engel, Nagy Lajos ismeretlen adományreformja, Történelmi Szemle, 1997/2, 137-157.

${ }^{22}$ Pál Engel, Az ország újraegyesítése, I. Károly küzdelmei az oligarchák ellen (1310-1323), Sz 1988, 89-146.

23 Pál Engel, Magyarország világi archontológiája, I-II, Budapest 1996; Исти, Magyarország világi archontológiája 1301-1457; Középkori magyar genealógia, Arcanum adatbázis kft 2001, CD-rom.

24 Ágnes Kurcz, Lovagi kultúra Magyarországon a 13-14. században, Budapest 1988.

${ }^{25}$ Vilmos Frankl, A nádori és orzágbirói hivatal eredete és hatáskörének történeti kifejlödése, Pest 1863. Géza Istványi, A generalis congregatio, Levélári közlemények, 17 (1939); Lajos Nyers, A nádor bírói és oklevéladó
} 
грбови ове породице те су на ову тему посебне радове давно написали Флорис Ромер (Rómer Flóris), Лајош Талоци (Thallóczy Lajos), Тивадар Лехоцки (Lehoczky Tivadar). ${ }^{26}$ Изузетно важну литературу за прошлост Другета чине и дела из области историјске географије, историје жупанија, тврђава и насеља који су се налазили у поседу ове породице. Значајан број чланака посвећен овој породици и њиховим поседима публикован је у земплинском историјском часопису Adalékok Zemplénvármegye Történetéhez крајем XIX и почетком XX века, посебно од стране рођеног сенћанина Ђуле Дудаша (Dudás Gyula), као и других историчара ове средине. ${ }^{27}$ Од још већег значаја за тему су историјско-географска медиевистичка дела Чанкија Дежеа (Dezső Csánki), Ђерђа Ђерфија (Györffy György), Бранислава Варсика (Branislav Varsik), Јана Бењка (Ján Beňko). ${ }^{28}$ Свакако међу наведенима треба истакнути и Фердинанда Уличног (Ferdinand Uličný), писца три велике монографије о насељима Шаришке, Ушке и Земплинске жупаније у којима налазимо прегршт корисних података о породици Другет и њиховим поданицима. ${ }^{29}$ Овој групи литературе непходно је придодати и посебно вредну књигу историчара-археолога Михала Сливке (Michal Slivka) и Адријана Валашека (Adrián Vallašek) о тврђавама на простору источне Словачке. ${ }^{30}$ Коначно, неоправдано би било изоставити књигу која сваком ко се прихвати да напише нешто о Другетима на врхунцу њихове моћи (тридесете године XIV века) отвора шире видике. Ради се о делу Ондреја Халаге (Ondrej Halaga) посвећеном средњовековним економским везама места Кошица, области тадашње горње Угарске и Балтика у коме се дакако налази обиље података о пословним интересима и клијентима Другета. Склоност ка пословима везаним за новац Другети су у Угарску донели из Италије и у том погледу су се разликовали од остатка угарске аристократије. ${ }^{31}$

Коначно, пред сваког истраживача ваља ставити књигу Штефана Ленчиша (Štefan Lenčiš) Šlachtickỳ rod Drugetovcov z Humenného, публиковану у некад куријалном месту Другета - Humenné 2003. године. У њој је аутор, углавном прегледно, покушао да прикаже историјат Другета од средине друге половине XIII

\footnotetext{
müködése a XIV. században, Kecskemét 1934; Iván Bertényi, Az országbírói intézmény története a XIV. században, Budapest 1976.

${ }^{26}$ Flóris Rómer, Régi pecséteinkröl s különösen Drugeth János 1332-iki pecsétéröl, Sz 1875, 54-59; Lajos Thallóczy, Adalék a Drugeth-család czimeréhez, Archeológiai Értesítő, 1879, 184-187; Tivadar Lehoczky, A Drugeth - és Althan - család - czímereiröl, T 1884, 81-82.

${ }^{27}$ Gyula Dudás, A Homonnai Drugeth-birtokok történetéhez, Adalékok Zemplénvármegye Történetéhez (AZT), 1906 180-181; Исти, А Нотоnna történetéhez, AZT, 1908, passim; Исти, Barkó vára, AZT, 1909, 49-50; Исти, Egy okirat a Homonnai- Drugeth emlékekböl, AZT, 1911, 49-50; Исти, Zemplénvármegye északi részének kialakulásáról, Homonna helységnek elsö földesurai, AZT, 1910, 193-195.

${ }^{28}$ Dezső Csánki, Magyarország történelmi földrajza a Hunyadiak korában, I, Budapest 1890; György Györffy, Az Árpád-kori Magyarország történeti földrajza, I, Budapest 1963; Branislav Varsik, Osídlenie Košičkej kotliny, I-III, Bratislava, 1964, 1973, 1977; Ján Beňko, Osídlenie severného Slovenska, Košice 1985.

${ }^{29}$ Ferdinand Uličný, Dejiny osídlenia Šariša, Košice 1990; Исти, Dejiny osídlenia Užskej župy, Prešov 1995; Исти, Dejiny osídlenia Zemlínskej župy, Mihalovce 2001.

${ }^{30}$ Michal Slivka, Adrián Vallašek, Hrady a hrádky na východnom Slovensku, Košice 1991.

${ }^{31}$ Ondrej Halaga, Košice - Balt, Výroba a obchod v styku výhodnoslovenskýh miest s pruskom (1275-1526), Košice 1975.
} 
века до изумирања фамилије по мушкој линији 1691. године. Ленчишев рад пружа корисне информације везане за библиографију старије литературе и поједине изворе. Недавни чланак Ференца Питија (Piti Ferenc) о смрти Виљема Другета и промени на палатинском положају Угарске 1342. године након Енгелових радова значајно је употпунио приступ овом проблему и посведочио да су Другети и даље отворена историографска тема. ${ }^{32}$

Историјат ове породице ипак превазилази претходно приказане оквире мађарске и словачке историографије. О Другетима се с правом може говорити као о много широј историографској теми. За почетак, Другете на више места помиње француски историчар, стручњак за анжујску власт у Италији, Емил Леонард (Émile Léonard) у свом класичном делу Les Angevins de Naples. ${ }^{33}$ На другом крају историографског хоризонта у нашој научној средини (на први поглед помало неиочекивано) из анонимности ови угарски палатини излазе захваљујући радовима зналца средњовековних српско-мађарских односа Петра Рокаија, ${ }^{34}$ а у последње време и неким нашим прилозима. ${ }^{35}$ Име Другета такође је присутно у радовима хрватских $^{36}$, пољских ${ }^{37}$ и украјинских историографа, ${ }^{38}$ захваљујући пре свега чињеници да су Другети као угарски барони и палатини предводили угарске краљевске војске у походима против хрватског бана Младена Шубића 1324. године,

\footnotetext{
${ }^{32}$ Ferenc Piti, Az 1342. évi nádorváltás, Sz 140, 2/2006, 435-441.

${ }^{33}$ Émile Léonard, Les Angevins de Naples, Paris 1954, 303, 313, 496.

${ }^{34}$ Петар Рокаи, Краљ Жигмунд и Угарска према Србији после Косовске битке, Глас CCCLXXVIII Cрпске академије наука и уметности, Одељење историјских наука, књ. 9, 1996, 148; Петар Рокаи, Золтан Ђере, Тибор Пал, Александар Касаш, Историја Мађара, Београд 2002, 103.

${ }^{35}$ Ђура Харди, Виљем Другет - закупаи мале и велике десетине у „Сремској земљи” 1330. године, Споменица Историјског архива „Срем”, 5, 2006, 33-48; Исти, Другет Виљем, „наследник” шест жупанија, Истраживања, 17, Нови Сад 2007, 27-33; Исти, Testament jednog Napolitanca u Ugarskoj kao izvor za njegovo poslovanje 1330. godine, Zbornik radova, Panonija - Balkan - Sredozemlje, Novi Sad 2007, 52-60; Исти, „Thelonea Domini Philippi Drugethi” (Carine gospodara Filipa Drugeta), Годишњак Филозофског факултета у Новом Саду, Књига XXXIV (2009), 2, 277-284; Исти, Личне везе палатина Филипа Другета с представницима нове анжујске елите или један прилог о животу на двору угарског краља Карла Роберта, Истраживања, 21, Нови Сад 2010, 93-102; Исти, Присуство породице Другет на тлу јужне Угарске током прве половине XIV века, Споменица Историјског архива „Срем”, 9, 2010, 11-23. ${ }^{36}$ Ferdo Šišić, Pad Mladena Šubića, bana hrvatskoga i bosanskoga, Glasnik Zemaljskog muzeja u Bosni i Hercegovini, 14 (1902), 353-354.

${ }^{37}$ Jan Dąbrowsky, Z czasów Lokietka, studya nad stosunkami polsko-węgierskimi w XIV w, część I, Kraków 1916, 48-49; Исти, Ostatni lata Ludwika Wielkiego 1370-1382, Kraków 2009, 13, 30, 100; Stanisław Zajączkowski, Polska a Zakon Krzyżacki w ostatnich latach panowania Władysława Łokietka, Lwów 1929, 139166.

${ }^{38}$ Михайло Грушевський, Історія України-Руси, IV, Київ 1993, 21, 435-436; Мирослав Волощук, Андрій Стасюк, Про похід палатина Віллерма in Rutheniam y квітні 1340 p, Вісник Прикарпатського університету, Історія, Вип. 17, 2010, 46-54; Мирослав Волощук, До питання східнослов'янського походження Петра Петуні, Український історичний журнал, 3, 2011, 20-33; Омелян Ставровський, Словацько-польско-українське прикордоння до 18 століття, Prešov 1967, passim; Степан Пап, История Закарпаття, I-III, Ивано-Франківськ, 2001, passim; (Іван М. Гранчак) Нариси історії Закрпаттяї, Том I (з найдавніщих часів до 1918. року) Вид. редактор і керівник авторсьского колективу Іван М. Гранчак, Ужгород 1993, 60, 66, 73.
} 
те као савезници Пољске били присутни на походима против Немачког витешког реда у Прусији 1330. године или против руске кнежевине Галиције 1340. године.

Посебан осврт ипак заслужује италијанска историографија. Рекосмо да је након спаљивања Напуљског архива 1943. године изгледало да је о Другетима у јужној Италији све речено, поготово из перспективе истраживача теме с друге стране Јадранског мора. У погледу доступне грађе, историчари су се силом прилика морали уздати у вредна истраживања поменутог Липота Оварија, ${ }^{39}$ а затим и на радове Хампела и Мишколција. Међутим, захваљујући труду архивисте Рикарда Филађерија (Ricardo Filangieri) и његових ученика педесетих година XX века започела је са излажењем велика едиција реконструкција анжујских извора Напуљског архива. До данас је публиковано 48 томова у којима се налази више десетина регести и докумената непосредно везаних за Другете, ${ }^{40}-$ околност која је само регистрована код неких историчара, али не и искориштена за тему коју разматрамо у овом чланку. ${ }^{41}$ У међувремену, имајући на располагању стицајем околности преостале, (махом публиковане) сачуване изворе, италијанска историографија је наставила свој рад - Другети ипак нису остали tabula rasa. Наиме, у покушају да након толико времена опет отворимо питање прошлости Другета у њиховој „првој домовини” Напуљској краљевини, сусрели смо се с радом италијанског аутора Ђакинта Либертинија (Giacinto Libertini), Origini di Pascarola посвећеном наполитанском месту Паскарола које је припадало управо породици Другет, а затим и с две историјско-географске монографије, публиковане у едицији Instituto di studi Atelani управо под Либертинијевим уредништвом о прошлости и развоју насеља из Напуљске провинције. ${ }^{42}$ За нас је то било драгоцено хеуристичко откриће које обећава писање нових поглавља из историје породице. За почетак, компаративним приступом у проучавању извора релевантних за историју породице назире се могући резултат будућих истраживања. Наиме, истраживачу се намеће хипотеза да је породица захваљујући својим поседима, пословним интересима и пре свега захваљујући утицају на краљевским дворовима Напуља и Вишеграда током прве половине XIV века била „снажно присутна” не само у Угарској већ

\footnotetext{
39 Липот Овари је 1865. године у Напуљу прегледао до тада сачуване Анжујске регистре (Registri Angioini), служећи се притом и волумозним рукописним делом исписа (регести) анжујских извора чувеног напуљског историчара и генеалога XVII века Карла де Лелиса (Carlo De Lellis) - Notamenta ex registris Caroli II, Roberti et Caroli ducis Calabriae. Оваријеви исписи су најкомплетније презентовани у двотомном издању Густава Венцела (Wenzel Gustáv, Magyar diplomacziai emlékek, Monumenta Hungariae Historica, Acta Extera, I-II, Budapest 1874-1875).

${ }^{40}$ I Registri della Cancelleria Angioina ricostruiti con la collaborazione degli Archivisti Napoletani, I-XLVIII, Napoli 1950-2004.

${ }^{41}$ Тек уопштено Фланђеријеву едицију помиње у свом занимљивом раду Enikő Csukovits, Az Anjou-kori intézményi újítások nápolyi párhauzamai, Honoris causa, Tanulmányok Engel Pál tiszteletére, Szerk. Tibor Neumann és György Rácz, Budapest-Piliscsaba 2009, 23.

${ }^{42}$ Giacinto Libertini, Origini di Pascarola, Rassegna Storica dei Comuni, n. 120-121, settembre-decembre 2003, 1-16; Persistenza di luoghi e toponimi nelle terre delle antiche citta' di Atella e Acerrae, (a cura di Giacinto Libertini) Instituto di studi Atelani, Frattamaggiore 1999; Documenti per la storia di Caivano, Pascarola, Casolla Valenzano e Sant' Arcangelo, (a cura di Giacinto Libertini) Instituto di studi Atelani, Frattamaggiore 2003.
} 
истовремено и у Напуљској краљевини. Та присутност се по универзалном обрасцу поклапала с политичком моћи ове породице. Када је она ишчезла, једноставно је нестало и Другета из далековида извора и историографије.

Мада знамо да су извори кључ за свако историографско постигнуће, о њима смо спремни да детаљно говоримо неком другом приликом. Сумарно речено, на стотине средњовековних докумената с поменом Другета публиковано је у скоро свим дипломатарима средње Европе. ${ }^{43}$ Та околност је пре свега последица палатинског и баронског статуса породице. Непубликоване изворе ваља тражити у архивима и њиховим збиркама попут фонда Druget - Humenné у Прешовском државном архиву у месту Нижна Шебестова у републици Словачкој. ${ }^{44}$ Највећи број докумената за историју породице налази се похрањен у Magyar Országos Levéltár-у у Будимпешти у фондовима Mohács elötti gyüjtemény (Collectio Antemohacsiana) и Diplomatikai fényképgyüjtemény. Корисне повеље о Другетима могу се наћи у Братислави у Словачком народном архиву (Slovenský národný archív) у фонду Hodnoverné miesto Leleský konvent, коначно и у бечком Haus-, Hof- und Staatsarchiv-y - збирци Allgemeine Urkundenreihe. Угарски, пољски и пруски хроничари држали су за сходно да помену чланове ове породице у својим делима у којим је место било резервисано тек за владаре и одабране.

Другети у једном тренутку европске историје јесу били одабрани као њени сведоци и судеоници. Пошло им је то за руком захваљујућ околности да су низ деценија, од средине XIII до средине XIV века стајали у најближем окружењу анжујске владарске династије која је владала земљама од Провансе до Паноније. То није промакло историографији чије смо главне прегаоце и њихове путеве на пољу званом историја породице Другет у средњем веку, почев од XVIII века (од када је тема присутна у историјској науци), настојали да нотирамо у овом раду. За све друге који су из објективних околности овом приликом изостављени претпостављамо да ће бити места у напоменама неке будуће монографије.

Извори и литература:

Извори:

Anjou-kori oklevéltár, Dokumenta res Hungaricas tempre regum Andegavensium illustrantia, Szerk. Kristó Gyula. Budapest-Szeged, 1990-.

Codex diplomaticus Hungariae ecclesiasticus ac civilis, ed. Georgius Fejér, I-XI, Budapest 18291844.

\footnotetext{
${ }^{43}$ Сем поменутих издавача едиција издвајамо: Imre Nagy, Gyula Tasnádi Nagy, Anjoukori okmánytár, Codex diplomaticus Hungaricus Andegavensis I-VII, Budapest 1878-1920; Anjou-kori oklevéltár, Dokumenta res Hungaricas tempre regum Andegavensium illustrantia, Szerk. Kristó Gyula. Budapest-Szeged, 1990-; Regesta Diplomatica nec non epistolaria Slovaciae, ad edendum praeparavit Vincent Sedlák, t. I-II, Bratislavae 19801987.

${ }^{44}$ Štatny archív Prešov, pobočka Nižná Šebestová, Druget - Humenné.
} 
I Registri della Cancelleria Angioina ricostruiti con la collaborazione degli Archivisti Napoletani, IXLVIII, Napoli 1950-2004.

Ioannes Bocatius, Opera quae exstant omnia, Poetica 1, ed. Franciscus Csonka, Budapest 1990.

Katona, Stephanus, Historia critica regum Hungariae stirpis mixtae, tomulus I, ordine VIII, (ab anno Ch. 1301 ad annum usque 1331), Budae 1788.

Libertini Giacinto Documenti per la storia di Caivano, Pascarola, Casolla Valenzano e Sant' Arcangelo, Instituto di studi Atelani, Frattamaggiore 2003.

M. Joannis Bocatii Poëtae Laureati Caesarei Hungaridos libri poematum V, Funeri Spectabilis, Magnifici et generosissimi Domini, D. Stephani Drugeth, Lib. Bar. de Homonna etc, Bartphae 1599.

Nagy, Imre,Tasnádi, Nagy Gyula, Anjoukori okmánytár, Codex diplomaticus Hungaricus Andegavensis, I-VII, Budapest 1878-1920.

Regesta Diplomatica nec non epistolaria Slovaciae, ad edendum praeparavit Vincent Sedlák, t. I-II, Bratislavae 1980-1987.

Štatny archív Prešov, pobočka Nižná Šebestová, Druget - Humenné.

Wagner, Carolus, Analecta Scepusii sacri et profani, tomus I-IV, Viennae (I-II); Posonii et Casoviae (III-IV) 1774-1778.

Wagner, Carolus, Diplomatarium Comitatus Sarosiensis. Posonii et Cassoviae 1780.

Wenzel, Gustáv, Magyar diplomacziai emlékek, Monumenta Hungariae Historica, Acta Extera, I-II, Budapest 1874-1875.

\section{Литература:}

Archivo di stato di Napoli, Guida generale degli Archivi di stato italiani, vol. III, N-R, Roma 1986.

Beňko, Ján, Osídlenie severného Slovenska, Košice 1985.

Bertényi, Iván, Az országbírói intézmény története a XIV. században, Budapest 1976.

Csánki, Dezső, Magyarország történelmi földrajza a Hunyadiak korában, I, Budapest 1890.

Csukovits, Enikő, Az Anjouk birodalma 1301-1387, Magyarország története, 5, Budapest 2009.

Csukovits, Enikő, Az Anjou-kori intézményi újítások nápolyi párhauzamai, Honoris causa, Tanulmányok Engel Pál tiszteletére, Szerk. Tibor Neumann és György Rácz, BudapestPiliscsaba 2009, 19-62.

Dąbrowsky, Jan, Ostatni lata Ludwika Wielkiego 1370-1382, Kraków 2009.

Dąbrowsky, Jan, Z czasów Łokietka, studya nad stosunkami polsko-węgierskimi w XIV w, część I, Kraków 1916.

Dudás, Gyula, A Homonna történetéhez, AZT, 1908.

Dudás, Gyula, A Homonnai Drugeth-birtokok történetéhez, AZT, 1906 180-181.

Dudás, Gyula, Barkó vára, Adalékok Zemplénvármegye Történetéhez (= AZT), 1909, 49-50.

Dudás, Gyula, Egy okirat a Homonnai- Drugeth emlékekböl, AZT, 1911, 49-50.

Dudás, Gyula, Zemplénvármegye északi részének kialakulásáról, Homonna helységnek elsö földesurai, AZT, 1910, 193-195.

Frankl, Vilmos, A nádori és orzágbirói hivatal eredete és hatáskörének történeti kifejlödése, Pest 1863.

Györffy, György, Az Árpád-kori Magyarország történeti földrajza, I, Budapest 1963.

Halaga, Ondrej, Košice - Balt, Výroba a obchod v styku výhodnoslovenskýh miest s pruskom (1275-1526), Košice 1975.

Hampel, József, A Drugetek őseiről, I-II közlemény, Századok (=Sz), 1881, 133-145, 207-213.

Hóman, Bálint,Szekfü, Gyula, Magyar történet, II, írta Hóman Bálint, Budapest 1939.

Hóman, Bálint, Gli Angoini di Napoli in Ungeria 1290-1403, Roma 1938.

Istványi, Géza, A generalis congregatio, Levélári közlemények, 17 (1939). 
Kristó, Gyula, A feudális széttagolódás Magyarországon, Budapest 1979.

Kristó, Gyula, A rozgonyi csata, Budapest 1978.

Kristó, Gyula, Az Anjou-kor háborúi, Budapest 1988.

Kristó, Gyula, Csák Máté tartományúri hatalma, Budapest 1973.

Kurcz, Ágnes, Lovagi kultúra Magyarországon a 13-14. században, Budapest 1988.

Lehoczky, Tivadar, A Drugeth - és Althan - család - czimereiröl, T (= Turul), 1884, 81-82.

Léonard, Émile, Les Angevins de Naples, Paris 1954.

Libertini, Giacinto, Origini di Pascarola, Rassegna Storica dei Comuni, n. 120-121, settembredecembre 2003, 1-16.

Libertini, Giacinto, Persistenza di luoghi e toponimi nelle terre delle antiche citta' di Atella e Acerrae, Instituto di studi Atelani, Frattamaggiore 1999.

Magyar írók, élete és munkái, írta József Szinnyei, I, Budapest 1891.

Malovecká, Milota, Karol Wagner /1732/1790/ historik Spiša a Šariša, Prešov 2009.

Miskolczy, István, A Drugetek öseiröl, T. 50, 1936, 1-5.

Miskolczy, István, Anjou-királyaink reformjai és a nápolyi viszonyok, I-II, Sz, 1932, 306-322, 393407.

Miskolczy, István, Magyar-olasz összeköttetések an Anjouk korában, Budapest 1937.

Nagy, Iván, Magyarország családai, Czímerekkel és nemezedékrendi táblákkal, III, Pest, 1858.

Nyers, Lajos, A nádor birói és oklevéladó müködése a XIV. században, Kecskemét 1934.

Pál, Engel, A nemesi társadalom a középkori Ung megyében, Budapest 1998.

Pál, Engel, Az ország újraegyesítése, I. Károly küzdelmei az oligarchák ellen (1310-1323), Sz, 1988, 89-146.

Pál, Engel, Druget, Korai magyar történeti lexikon (9-14. század), főszerkesztő Kristó Gyula, Budapest 1994, 174.

Pál, Engel, Kristó Gyula, Kubinyi András, Magyarország története 1301-1526, Budapest 2002.

Pál, Engel, Magyarország világi archontológiája 1301-1457; Középkori magyar genealógia, Arcanum adatbázis kft 2001, CD-rom.

Pál, Engel, Magyarország világi archontológiája, I-II, Budapest 1996.

Pál, Engel, Nagy Lajos ismeretlen adományreformja, Történelmi Szemle, 1997/2, 137-157.

Palatini regni Hungariae bello paceque clarissimi, (Barinyay István), Tyrnaviae. 1753, 64-68.

Piti, Ferenc, Az 1342. évi nádorváltás, Sz, 140, 2/2006, 435-441.

Pór, Antal, Gyula, Schöner, Az Anjou ház és örökösei (130-1439), A magyar nemzet története, szek. Szilágyi Sándor, Budapest 1895.

Réz, László, Drugetek és Homonna reformátiója, Sátoralja-újhely, 1899.

Rómer, Flóris, Régi pecséteinkröl s különösen Drugeth János 1332-iki pecsétéröl, Sz, 1875, 54-59.

Slivka, Michal, Vallašek Adrián, Hrady a hrádky na východnom Slovensku, Košice 1991.

Szirmay, Antonium Notitia historica comitatus Zempléniensis, Budae 1804.

Szirmay, Antonium, Notitia topographica, politica inclyti comitatus Zempléniensis, Budae 1803.

Šišić, Ferdo, Pad Mladena Šubića, bana hrvatskoga i bosanskoga, Glasnik Zemaljskog muzeja u Bosni i Hercegovini, 14 (1902), 353-354.

Thallóczy, Lajos, Adalék a Drugeth-család czimeréhez, Archeológiai Értesítő, 1879, 184-187.

Uličný, Ferdinand, Dejiny osídlenia Šariša, Košice 1990.

Uličný, Ferdinand, Dejiny osídlenia Užskej župy, Prešov 1995.

Uličný, Ferdinand, Dejiny osídlenia Zemlínskej župy, Mihalovce 2001.

Varsik, Branislav, Osídlenie Košičkej kotliny, I-III, Btatislava, 1964, 1973, 1977.

Wagner, Carolus, Collectanea genealogico-historica illustrium Hungariae familiarum que jam interciderunt, Posonii, Pestini et Lipsiae 1802.

Wertner, Mór, A Drugeth-ek genealogiájához, T, 9, 1891, 151-154. 
Zajączkowski, Stanisław, Polska a Zakon Krzyżacki w ostatnich latach panowania Władysława Lokietka, Lwów 1929.

Волощук, Мирослав, До питання східнослов'янського походження Петра Петуні, Український історичний журнал, 3/2011, 20-33.

Волощук, Мирослав, Стасюк Андрій, Про похід палатина Віллерма in Rutheniam у квітні 1340 p, Вісник Прикарпатського університету, Історія, Вип.17, 2010, 46-54.

Грушевський, Михайло, Історія Украӥни-Руси, IV, Київ 1993.

Нариси історії Закрпаттяї, Том I (з найдавніщих часів до 1918. року) Вид. редактор і керівник авторсьского колективу Іван М. Гранчак, Ужгород 1993.

Пап, Степан , История Закарпаття, I-III, Ивано-Франківськ, 2001.

Рокаи, Петар, Ђере Золтан, Пал Тибор, Касаш Александар, Историја Мађара, Београд 2002.

Рокаи, Петар, Краљ Жигмунд и Угарска према Србији после Косовске битке, Глас CCCLXXVIII Српске академије наука и уметности, Одељење историјских наука, књ. 9, 1996,145-150.

Ставровський, Омелян, Словаџько-польско-українське прикордоння до 18 століття, Prešov 1967.

Харди, Ђура, „Thelonea Domini Philippi Drugethi” (Carine gospodara Filipa Drugeta), Годишњак Филозофског факултета у Новом Саду, Књига XXXIV (2009) - 2, 277284.

Харди, Ђура, Testament jednog Napolitanca и Ugarskoj kao izvor za njegovo poslovanje 1330. godine, Zbornik radova, Panonija - Balkan -Sredozemlje, Novi Sad 2007, 52-60.

Харди, Ђура, Виљем Другет - закупаи мале и велике десетине у „Сремској земљи” 1330. године, Споменица Историјског Архива „Срем”, 5/2006, 33-48.

Харди, Ђура, Другет Виљем, „наследник” шест жупанија, Истраживања, 17, Нови Сад 2007, 27-33.

Харди, Ђура, Личне везе палатина Филипа Другета с представничима нове анжујске елите или један прилог о животу на двору угарског краља Карла Роберта, Истраживања, 21, Филозофски факултет у Новом Саду, Одсек за историју, Нови Сад 2010, 93-102.

Харди, Ђура, Присуство породище Другет на тлу јужне Угарске током прве половине ХIV века, Споменица Историјског Архива „Срем”, 9/2010, 11-23. 


\title{
ĐURA HARDI
}

\section{HISTORIOGRAPHY OF THE DRUGET'S FAMILY IN THE MIDDLE AGES}

\begin{abstract}
Summary
The paper analyzes the Anjou noble family of Druget's in the Middle Ages as a historiographic issue. Over the past 200 years, the Druget's family was directly or indirectly a research subject of eight European historiographies: Hungarian, Slovak, Italian, French, Polish, Ukrainian, Serbian and Croatian. It was the case primarily because of its interesting, French - Naples origin, and influence they had as paladins in Hungary in the first half of the fourteenth century. However, the key point for the historiography regarding the history study of this family was the fire of the Naples State Archives in 1943. Since then, historians have focused on the family presence in Central Europe. Only recent findings from the papers of Italian historiography have again started the topic of the Druget's origin, which was 'the problem' since the infancy of the critical historiography dedicated to this family. The founder of the critical historiography on the history of the family was certainly Carolus Wagner. This erudite, historian, genealogist, and a publisher of historical sources, was actually the first researcher who systematically presented a history and genealogy of the Druget's family which was already dead. Wagner's text on the Druget's was published posthumously, in 1802, in the third volume of the famous Collectanea Genealogico-historica illustrium Hungariae familiarum interciderunt que jam.
\end{abstract}

Keywords: the Druget's, historiography, history of medieval noble families. 